\title{
Analiza mechanizmów zachowania spójności w komunikacie multimodalnym na przykładzie relacji na żywo, w ramach teorii modelu sytuacji; propozycja modelu spójności dla telewizyjnego przekazu reporterskiego
}

\author{
Agnieszka Czoska \\ Instytut PsychologiI, UnIWERSYTET IM. ADAMA MiCKIEWICZA \\ aczoska@amu.edu.pl \\ Agata Karaśkiewicz \\ INSTYTUT JĘZYKOZNAWSTWA, UNIWERSYTET IM. ADAMA MICKIEWICZA \\ AL. NiEPODLEGŁOŚCI 4, 61-874 PoZNAŃ \\ agata.karaskiewicz@wp.pl
}

\begin{abstract}
Abstrakt
W artykule przedstawiono model spójności komunikatu multimodalnego skonstruowany $\mathrm{z}$ perspektywy modelu przetwarzania tekstu Event-Indexing Model. Podejście to pozwala na wyróżnienie dwóch perspektyw analizy spójności komunikatu multimodalnego: paralelnej oraz sekwencyjnej. Umożliwia także porównanie stopnia spójności różnych typów komunikatów multimodalnych oraz przewidywanie wpływu zmian poziomu spójności na przetwarzanie komunikatu. Proponowany model daje możliwość analizy spójności zarówno z punktu widzenia odbiorcy, jak i nadawcy komunikatu.
\end{abstract}

\begin{abstract}
The paper presents a model of multimodal message coherence based on Event-Indexing Model of text processing. The approach proposed here enables differentiating between two perspectives on multimodal message coherence: parallel and sequential. It also provides means for comparing the levels of coherence in messages of different types and making predictions concerning how changes in the coherence level may affect processing of a message. Moreover, the model proposed
\end{abstract}


in the paper allows coherence analysis from the point of view of both the author and the audience.

\section{Wprowadzenie}

Komunikat multimodalny operuje kilkoma systemami znakowymi jednocześnie (Peach 1975). Odbiorca takiego komunikatu musi zintegrować informacje pochodzące z różnych kanałów w jedną całość. Informacje przekazywane za pomocą każdego systemu mogą być ze sobą spójne w różnym stopniu.

Komunikaty telewizyjne, jak relacje na żywo (RNŻ) mają charakter multimodalny. Rodzi się tu pytanie o sposoby zachowania spójności w multimodalnym komunikacie telewizyjnym o charakterze informacyjnym. W literaturze poświęconej zagadnieniu spójności pojawia się co najmniej kilka jej rodzajów oraz typologii środków służących do jej utrzymania. Na gruncie językoznawstwa, także w przypadku komunikatów multimodalnych, podejmuje się przede wszystkim problem kryteriów spójności warstwy werbalnej komunikatów (zob. np. Mayenowa, 1971; de Beaugrande, Dressler 1981; Dobrzyńska, 1993; Bellert, 1971; Saloni, 1971; Duszak 1998: 67-125; Żydek-Bednarczuk 2005: 79-113; Bartmiński, NiebrzegowskaBartmińska 2009; Hyland, 2005; Ädel, 2006) oraz jej korespondencji z warstwą niewerbalną (Leathers 2007: 325-340; Antas 2000: 285; Załazińska 2006: 113-201). Mniej uwagi poświęca się próbie zdefiniowania spójnego, złożonego pod względem strukturalnym, komunikatu medialnego. Prowadzone w tym kierunku badania ograniczają się głównie do analizy wpływu powiązania (lub jego braku) między dwiema ścieżkami: wizualną oraz werbalną (Brosius et al., 1996; Lang, 1995, Meinhof 1994; Walma van der Molen 2001;) na rozumienie przekazu, jak i tego, który z komponentów umożliwia lub ułatwia jego przetworzenie.

W niniejszym artykule przedstawiono propozycję podejścia do zagadnienia (zachowania i utrzymania) spójności w komunikacie multimodalnym z perspektywy modelu sytuacji, opisującego proces rozumienia komunikatu w terminach konstrukcji reprezentacji przedstawianego w komunikacie wydarzenia (Zwaan, Langston i Graesser, 1995; Zwaan i Radvansky, 1998). W ramach proponowanego modelu elementy składowe relacji na żywo (live) zostaną scharakteryzowane pod względem ich potencjalnego wpływu na spójność komunikatu. Analizie poddane zostaną mechanizmy utrzymania oraz zwiększania spójności stosowane przez nadawców relacji, jak i zjawiska utrudniające odbiorcom proces aktualizacji modelu mentalnego komunikatu.

\section{Komunikat multimodalny w postaci RNŻ}
. Aktualnie relacje z miejsc, gdzie dzieje się coś ważnego, są standardowym sposobem przekazywania informacji, można je znaleźć w każdym serwisie informacyjnym.

Relacja ze zdarzeń rozgrywających się w czasie rzeczywistym, to łączenie podczas programu na żywo z reporterem, który jest na miejscu omawianych wydarzeń (Uszyński 2004). Wyróżnić można kilka rodzajów relacji na żywo (RNŻ) ze względu na ich strukturę, tj. a) w „czystej postaci”, bez wypowiedzi innych osób, rozmów z gośćmi etc., b) z setka- wypowiedź do kamery świadków wydarzeń lub np. ekspertów mających coś w danej sprawie do powiedzenia (Uszyński 2004). Może być ich kilka w trakcie jednej relacji, c) w formie dialogu - rozmowy z gościem, d) w formie rozmowy telefonicznej oraz pełnioną funkcję: a) RNŻ 
Agnieszka Czoska, Agata Karaśkiewicz: Analiza mechanizmów zachowania spójności $w$ komunikacie multimodalnym na przykładzie relacji na żywo, $w$ ramach teorii modelu sytuacji; propozycja modelu spójności dla telewizyjnego przekazu reporterskiego

zapowiada newsa, który ma rozwinąć podjęty temat, b) news jest zapowiedzią RNŻ, która jest jego uzupełnieniem. Warunkiem sklasyfikowania relacji jako RNŻ jest obecność reportera na miejscu zdarzenia, które ma on relacjonować. Relacjonuje to, co zobaczył oraz usłyszał, pełni on rolę „narratora obecnego na scenie opisywanych zdarzeń” (Magdoń 2005).

\section{Struktura RNŻ}

RNŻ buduje się na zasadzie odwróconej piramidy, struktury przejętej z prasy (Niczyperowicz 2001). Najważniejsze fakty znajdują się na początku. Potem następuje rozwinięcie tematu (body), informacje są rozbudowywane, uzupełniane o szczegóły w kolejności ważności (wg reportera). Kontekst RNŻ obejmuje biała, czyli zapowiedź oraz pytanie prowadzącego ze studia wraz z relacją reportera obecnego na miejscu wydarzenia (Uszyński 2004).

Zazwyczaj w momencie zapowiedzi na ekranie, poza prezenterem prowadzącym serwis, zobaczyć można w drugim oknie reportera, który oczekuje na „oddanie mu głosu” (tzw. picture-in-picture (Płażewski 1982)). Zapowiadając łączenie się z reporterem na żywo, prowadzący serwis informacyjny posługuje się zwrotami takimi jak: „na miejscu zdarzenia jest nasz reporter...”, „taczymy się z naszym reporterem...”, „a teraz przenosimy się do ..., gdzie jest nasz reporter...”. Użycie takiej konstrukcji wydaje się być reprezentatywnym wskaźnikiem, pozwalającym widzom przygotować się na relację prosto z miejsca zdarzenia, a więc pewną określoną estetykę przekazu. Słysząc taką zapowiedź, widzowie oczekiwać mogą pojawienia się na pierwszym planie reportera etc. Dodatkowo, łącząc się z reporterem na żywo, prowadzący dokładnie określa miejsce, z którego nadawany będzie przekaz. Pojawiają się także wyrażenia deiktyczne, odnoszące się do określenia czasu (teraz, obecnie, aktualnie, $w$ chwili obecnej, dzisiaj), co w połączeniu z określeniami przestrzeni (tutaj, w tym miejscu etc.), poza funkcją informacyjną, tworzy pewną strukturę, w ramach której widz może odnaleźć swoje miejsce (Allen 2006). Widz ma możliwość zapoznania się z kontekstem sytuacyjnym RNŻ: widzi reportera, jego zachowania oraz okoliczności i miejsce, w którym doszło do zdarzenia. RNŻ jest komunikatem o charakterze informacyjnym, w związku z czym z punktu widzenia nadawcy istotne powinno być, aby odbiorcy zrozumieli komunikat stworzyli model sytuacji przedstawionej w tekście.

\section{Model Event-Indexing}

Podstawę opracowania proponowanego tu modelu spójności komunikatu multimodalnego w postaci RNŻ stanowi model przetwarzania tekstu Zwaana i in. Event Indexing Model (EIM) (Zwaan i in., 1995; Zwaan i Radvansky, 1998; Zwaan, 1999; Zwaan i Madden, 2004; Rinck i Weber, 2003), opisujący proces rozumienia komunikatu $\mathrm{w}$ terminach konstrukcji reprezentacji przedstawianej w komunikacie sytuacji. Autorzy modelu zakładają, że odbiorca komunikatu (re)konstruuje przedstawioną w nim sytuację, stopniowo uaktualniając model 
przez dołączanie kolejnych wydarzeń (events). Centralnym procesem (re)konstrukcji w EIM jest monitorowanie spójności (ciągłości) sytuacji (Magliano, Miller i Zwaan, 2001) ${ }^{1}$.

Wydarzenie definiowane jest jako wystąpienie w komunikacie kolejnego czasownika (Zwaan i in., 1995; Zwaan i Radvansky, 1998), jednak na potrzeby niniejszej analizy definicja ta zostanie uogólniona do wystąpienia kolejnego predykatu w prototekście. Prototekst to proponowana w teorii TAM - Textual Architecture Model - reprezentacja komunikatu opisująca jego strukturę, formatowanie czy obecność infografik w formie metatekstowych predykatów z poziomu metajęzyka konstrukcji komunikatu (metalanguage; predykaty takie zawierają czasowniki performatywne nazywające akty komunikacyjne nadawcy - np. „definiuję”, „wyliczam”) (Lemarie, Lorch, Eyrolle i Virbel, 2008, Pascual i Virbel, 1996). Prototekst zawiera także treść komunikatu (Lemarie i in., 2008, Pascual i Virbel, 1996). Ma on przedstawiać architekturę tekstu (zawarte w nim informacje i jego strukturę) bez określania z góry sposobu jej realizacji w danym komunikacie (Lemarie, i in., 2008). Taka definicja wydarzenia pozwala uwzględnić jako elem enty składowe modelu sytuacji informacje i zmiany wprowadzane zarówno w warstwie werbalnej, jak i wizualnej komunikatu, tak, by można było mówić o wydarzeniach nie tylko w oparciu o tekst RNŻ (por. Zacks, Speer i Reynolds, 2009).

Każdemu wydarzeniu składającemu się na model sytuacji w modelu EIM przyporządkowuje się pięć indeksów pozwalających umiejscowić je w wymiarach uznanych za kluczowe dla zrozumienia treści komunikatu (przestrzeń, postaci i obiekty², przyczynowość, intencje (postaci) i czas) i powiązać ze skonstruowanym dotychczas modelem sytuacji.

Zwaan i Radvansky (1998) wyróżniają w swojej propozycji trzy typy modeli treści komunikatu, będące zarazem etapami konstrukcji modelu sytuacji przedstawianej w komunikacie. Model aktualny (current) obejmuje aktualnie przetwarzany element tekstu (pojedyncze wydarzenie). Model zintegrowany (integrated) integruje wszystkie już znane wydarzenia. Model kompletny (complete) powstaje po zakończeniu przetwarzania tekstu i jest zapisywany w pamięci długotrwałej.

Podstawową operacją składową procesu konstrukcji modelu sytuacji jest aktualizacja modelu zintegrowanego, oznaczająca dołączenie do niego modelu aktualnego (integrację modelu aktualnego ze zintegrowanym) 3 . Mechanizm ten jest najważniejszy także z punktu widzenia

\footnotetext{
1 ,the online monitoring of situational continuity is a central process in model construction" (Magliano $\mathrm{i}$ in., 2001, s. 533)

rozdzielany na 2 indeksy w metodologii stosowanej przez Zacksa i in. (Zacks, Speer i Reynolds, 2009;
}

Zacks, Kurby, Eisenberg i Haroutonian, 2011; Kurby i Zacks, 2012)

3 Opisane tu mechanizmy zachodzą automatycznie w trakcie przetwarzania komunikatu, nie wykluczają jednak dodatkowej, świadomej refleksji nad tekstem. Model EIM nie zakłada dwuetapowości przetwarzania tekstu jak na przykład klasyczny model Construction-Integration Kintscha (Ericsson i Kintsch, 1995; McNamara i Magliano, 2009; Hald, Steenbeek-Planting i Hagoort, 2007). Model EIM można porównać do popartego wieloma badaniami modelu przetwarzania tekstu proponowanego przez Hagoorta i van Berkuma (Hald, Steenbeek-Planting i Hagoort, 2007; van Berkum, Brown i Hagoort, 1999; van Berkum, Brown, Zwitserlood , Kooijman i Hagoort, 2005; Hagoort i van Berkum, 2007), który wskazuje na równoległość i jednoczesność przetwarzania 
Agnieszka Czoska, Agata Karaśkiewicz: Analiza mechanizmów zachowania spójności $w$ komunikacie multimodalnym na przykładzie relacji na żywo, $w$ ramach teorii modelu sytuacji; propozycja modelu spójności dla telewizyjnego przekazu reporterskiego

analizy spójności tekstu. Obecność w tekście wydarzenia niespójnego z przedstawianą sytuacją utrudnia lub uniemożliwia aktualizację modelu ze względu na niezgodność wartości indeksów.

Wykorzystanie modelu EIM do analizy komunikatów multimodalnych (integrowanie modelu sytuacji na podstawie informacji podawanych w różnych modalnościach) zostało zaproponowane przez samych twórców modelu (Zwaan i Radvansky, 1998,). Zdaniem Zwaana i Radvansky `ego (1998), dzięki teorii modeli sytuacji można wyjaśnić wyniki badań wskazujących na duże podobieństwo pamięciowych reprezentacji wydarzeń niezależnie od tego, czy odbiorcy przeczytali o nich w tekście, czy zobaczyli je np. na filmie. Propozycję tę w odniesieniu do innych teorii modeli mentalnych rozwinął także Persson (1998). Model został przetestowany w licznych badaniach empirycznych na tekstach pisanych (Rapp i Kendeou, 2007; Therriault, Rinck i Zwaan, 2006; Radvansky i Copeland, 2004; Rapp i Taylor, 2004; Rinck i Weber, 2003), w tym także w odniesieniu do działania szkicownika wzrokowoprzestrzennego, który odgrywa istotną rolę w przetwarzaniu bodźców wizualnych (Brunyé i Taylor, 2007), a także rozumienia filmu (Magliano, Miller i Zwaan, 2001; Zacks i in., 2009; Zacks i in., 2011).

\section{Spójność w EIM}

W modelu EIM spójność komunikatu opiera się na ciągłości indeksów opisujących wydarzenia. Aby możliwe było zintegrowanie aktualnego modelu z modelem zintegrowanym, przynajmniej jeden indeks $\mathrm{w}$ modelu aktualnym powinien mieć wartości identyczną $\mathrm{z}$ indeksem wydarzeń z modelu zintegrowanego. Im więcej wspólnych wartości indeksów, tym łatwiejsza jest aktualizacja modelu. Ich brak może skutkować koniecznością ponownego przetworzenia wartości indeksów (naprawą błędów w przetwarzaniu tekstu) lub uniemożliwić integracje modelu komunikatu. Wówczas, w sytuacji niespójności, odbiorca może rozpocząć konstrukcje nowego modelu sytuacji (uznać, że rozpoczął się nowy komunikat).

\subsection{Propozycja modelu spójności komunikatu multimodalnego na przykładzie RNं்}

\subsubsection{Spójność RNŻ}

W kontekście komunikatu multimodalnego możemy mówić o dwóch podstawowych aspektach spójności:

spójność w perspektywie paralelnej4 - warstwy werbalnej i wizualnej w danym momencie (oparta na redundancji audio-wideo), umożliwiająca konstrukcję pojedynczego wydarzenia z informacji podawanych w obu warstwach;

semantycznego i pragmatycznego, więc jednoczesność wpływu na przetwarzanie i integracje tekstu wiedzy semantycznej i encyklopedycznej odbiorcy.

4 terminy ,paralelny” i „,sekwencyjny” zostały zaczerpnięte z artykułu Popławskiego i Francuza (2004); 
spójność w perspektywie sekwencyjnej - z wydarzenia na wydarzenie, zwłaszcza pomiędzy kolejnymi elementami składowymi RNŻ (np. wypowiedziami reportera i rozmówców), umożliwiająca konstrukcję modelu sytuacji całego komunikatu.

Tabela 2 zawiera zestawienie proponowanych w modelu EIM indeksów z poszczególnymi elementami składowymi RNŻ, które mogą stanowić źródło informacji o wartościach poszczególnych indeksów5 . Można to traktować jako konkretyzację indeksów - odniesienie ich do omawianego tu rodzaju komunikatu multimodalnego. Ze względu na charakter RNŻ nadawanie na żywo z miejsca zdarzenia - najmniej zmieniać się będą wartości indeksów czas i przestrzeń, przy czym przestrzeń może podlegać zmianom na przykład ze względna na zmianę aspektu sytuacji, obiektu lub bohatera, który stanowi centrum (focus) danego elementu RNŻ (co może być związane na poziomie realizacji ze zmianą planu i ruchem kamery). Indeksem, którego wartość może zmieniać się najczęściej, będzie prawdopodobnie postaci i obiekty. Przy tym w zależności o tematu RNŻ ciągłość postaci lub obiektu będzie kluczowa dla uaktualniania modelu sytuacji.

\section{Tabela 2 Nośniki wartości indeksów modelu sytuacji relacji na żywo}

WYMIARY

MODELU

SYTUACJI

Przestrzeń

Postaci i obiekty

Przyczynowość

Biała, czyli krótka prezentacja tła wydarzenia; opis tła sytuacji i prośba o pojawiają się także w opisie wydarzenia podawanym przez reportera; Intencje

Czas wypowiedź lub pytanie do reportera; relacje przyczynowo-skutkowe

Cel przedstawiania danej sytuacji. Celem komunikacyjnym i nadrzędną

Otoczenie w którym przebywa reporter podczas nadawania relacji; nie będące przy tym tematem RNŻ

Reporter obecny na miejscu zdarzenia, bohaterowie zdarzenia (niekoniecznie pokazywani w warstwie wideo) lub obiekty istotne dla opisywanej sytuacji; funkcją realizowaną przez uczestników RNŻ jest przekazanie informacji na temat danego zdarzenia do opinii publicznej (funkcja poznawcza (Jakobson, 1986)).

Moment rozgrywania się wydarzenia („tu i teraz”); upływ czasu w czasie nadawania relacji

W proponowanym modelu stosować będziemy rozróżnienie na trzy poziomy spójności paralelnej, opisujące poziom korespondencji między kanałami wizualnym oraz werbalnym: całkowitej (overlap), niecałkowitej (displacement) oraz rozbieżność

5 na potrzeby niniejszego artykułu będziemy posługiwać się terminem ,nośnik” wartości indeksu w odniesieniu do elementu (w kanale audio lub wideo) komunikatu niosącego informacje o indeksowaniu daneg o wydarzenia. 
Agnieszka Czoska, Agata Karaśkiewicz: Analiza mechanizmów zachowania spójności w komunikacie multimodalnym na przykładzie relacji na żywo, $w$ ramach teorii modelu sytuacji; propozycja modelu spójności dla telewizyjnego przekazu reporterskiego

(dichotomy). Podział ten zaproponowany został przez Meinhofa (1994) Modyfikacje do klasyfikacji Meinhofa wprowadzita van der Molen (2001), używając innych określeń na relacje między obrazem a tekstem, analogicznie: direct, indirect, divergnet, ale przede wszystkim proponując czwartą kategorię, tzw. gadające głowy (talking heads). Odnosi się ona do sytuacji, w której na ekranie widoczne jest popiersie prowadzącego serwis lub zdającego relację z miejsca zdarzenia reportera, przy założeniu, że tło nie wprowadza dodatkowych informacji do tego, co mówi rozmówca. W sytuacji gdy tho wnosi dodatkowe informacje, gadające głowy zalicza się do jednej z trzech głównych kategorii (van der Molen 2001). Zdaniem Meinhofa (1994) całkowita spójność między komponentami wizualnym oraz werbalnym zachodzi bardzo rzadko.

Elementy składowe RNŻ można podzielić ze względu na ich znaczenie dla spójności paralelnej i sekwencyjnej. Pierwsza opiera się na relacji pomiędzy kanałem audio i wideo, co można sprowadzić do redundancji i kontekstu ekranowego. Drugą z kolei należałoby analizować poprzez stopień zgodności wartości indeksów EIM pomiędzy elementami mogącymi wystąpić w RNŻ: biata, pytaniem-odpowiedzia, setkami (patrz następny rozdział) oraz pomiędzy kolejnymi wypowiedziami, którymi reporter zarządza w ramach moderacji.

\subsubsection{Elementy składowe RNŻ, które mogą wprowadzać (nie)spójność do komunikatu i modelu sytu acji}

Zwaan i in. (Zwaan i in., 1995; Zwaan i Radvansky, 1998) analizują komunikat jako składający się z poszczególnych wydarzeń (events), nie wspominając o ich hierarchii ani podziałach tekstu. Zagadnienia związane z podziałem komunikatu na części składowe - np. tekstu na akapity, filmu na sceny czy ujęcia, nie są analizowane w ramach EIM. Z kolei teoria TAM uznaje wskazówki podziału komunikatu na części za ważne zarówno z punktu widzenia jego konstrukcji, jak i odbioru (Pascual i Virbel, 1996; Lemarié i in., 2008; Lorch, Lemarié, Grant, 2011).Połączenie podejść uwzględniających podział komunikatu z analizą na podstawie EIM jest możliwe, stosowane jest na przykład przez Zacksa i in. (2009; 2011).

Wyniki badań Zacksa i in. (2009) wskazują na to, że im więcej indeksów wymagaaktualizacji (im więcej różnic wartości indeksów pomiędzy sąsiadującymi wydarzeniami), tym większe prawdopodobieństwo, że dane wydarzenie zostanie przez odbiorcę uznane za granicę części 
składowej komunikatu. Wyniki te należałoby uwzględnić w analizie spójności komunikatu6 ${ }^{6}$ Na ich podstawie można przypuszczać, że spójność wydarzeń stanowiących granice części składowych komunikatu (i jednocześnie niespójnych ze sobą) będzie kluczowa z punktu widzenia spójności całego komunikatu.

Poniżej wyliczone zostały potencjalne elementy składowe RNŻ wraz ze strategiami zachowania spójności RNŻ, w momencie wprowadzania do niej nowego elementu. Mowa tu o „spójności nadawcy", tzn. strategiach stosowanych przez twórców RNŻ aby skonstruować komunikat w ich odczuciu tworzący spójną całość) W terminach EIM i TAM można traktować je jako instrukcje (dla odbiorcy) przetwarzania komunikatu w taki sposób, aby możliwa była (re)konstrukcja spójnego modelu sytuacji (Zwaan i in, 1995; Therriault, Rinck i Zwaan, 2006; Zwaan, 1999; Pascual i Virbel, 1996; Lemarie i in., 2008). W kolejnej części artykułu strategie te zostaną krótko przeanalizowane w kategoriach EIM z perspektywy odbiorcy.

\section{Perspektywa paralelna:}

Redundancjaaudio-wideo: Zgodność semantyczna w kanałach audio-wideo (Francuz 2002); pod uwagę brana jest redundancja paralelna (czyli zachodząca między różnymi kanałami).

Kontekst ekranowy: Tekst wypowiedzi funkcjonuje w RNŻ, podobnie jak np. w newsach, czy sprawozdaniach sportowych jako tekst towarzyszący, ściśle zespolony z kontekstem ekranowym (Ożdżyński 1978; Wesołowska 1980). Oznacza to, że reporter, wiedząc co znajduje się za nim, może explicite zwracać na to uwagę.

\section{Perspektywa sekwencyjna:}

a) Biata: Pytanie do reportera poprzedza często naprowadzenie w postaci krótkiego opisu tła zdarzenia i tematu relacji, czasem inne wypowiedzi, przypomnienie faktów lub dane dotyczące poruszanej kwestii, a dopiero potem formułowane jest wynikające z tematu pytanie (Uszyński 2004).

b) Setki lub rozmowy z gośćmi: Setki to, po pierwsze, wypowiedzi bohaterów do kamery. Po drugie, są nośnikami informacji, które łączy ze sobą tekst z offu (w newsie) lub wypowiedź reportera (RNŻ) (Żórawski 2012).

Zmiana planów: Podział na rodzaje planów jest umowny, wyróżnić można następujące: ogólny, pełny, amerykański, półzbliżenie, zbliżenie oraz duże zbliżenie (detal) (Płażewski 1982; Zonn 2001). Zmiana planów odnosi się do jednostek mniejszego rzędu w „języku filmu”. W jednym ujęciu plan może zmieniać się kilkakrotnie.

Pytanie-odpowiedź: Pytania zadawane reporterowi przez prowadzącego serwis formułowane są w taki sposób, by otrzymać zakładaną odpowiedź. Działania werbalne dziennikarza prowadzącego program, jak i reportera obecnego na miejscu zdarzeń

\footnotetext{
$6 \quad$ Zacks i in. $(2009 ; 2011)$ nie analizują spójnościkomunikatów, ale ich przewidywalność z punktu widzenia odbiorcy (prediction). Stosowana przez nich metodologia jest jednak porównywalna z badaniami dotyczącymi spójnościkomunikatu, zawiera jedynie dodatkowe pytania na przykład o to, czy odbiorca spodziewał się danej frazy w tekście.
} 
Agnieszka Czoska, Agata Karaśkiewicz: Analiza mechanizmów zachowania spójności $w$ komunikacie multimodalnym na przykładzie relacji na żywo, $w$ ramach teorii modelu sytuacji; propozycja modelu spójności dla telewizyjnego przekazu reporterskiego

ukierunkowane są bardziej na oddziaływanie na widzów i słuchaczy niż na rozmówcę, dlatego reporter dąży do uzyskania pełnej, właściwej odpowiedz. Oprócz „podstawowej odpowiedzi”, reporter często odnosi się do zapowiedzi/pytania prowadzącego („tak jak powiedziałeś, sprawy nie udało się dotąd wyjaśnić”; „dokładnie tak...”; „masz rację..”). Jeśli prowadzący uzna, że odpowiedź reportera nie była wyczerpująca, a jest jeszcze czas na dopytanie, zadaje kolejne pytania, ściśle powiązane z poprzednią wypowiedzią reportera. W RNŻ rzadkością są pytania rozstrzygnięcia, wymagające odpowiedzi tak lub nie, bez możliwości podjęcia próby wyjaśnienia okoliczności. Czasem prowadzący jednak zmuszony jest przerwać relację, jeśli jest za długa. Nie ma bowiem ściśle określonego czasu przeznaczonego na odpowiedź reportera, zależne jest to m.in. od producenta programu. O tym, że wypowiedź lub odpowiedź reportera na pytanie ze studia dobiega ku końcowi, że chce on oddać „głos” do studia, świadczyć mogą sekwencje niewerbalne (Poyataos 2002). Sygnałami sugerującymi zakończenie wypowiedzi reportera mogą być zwolnienie tempa wypowiedzi, obniżenie głosu, opadająca intonacja, a nawet zakłopotanie na twarzy dziennikarza.

e) Moderacja wymiany zdań: Jedną z nadrzędnych ról dziennikarza prowadzącego program jest nieustanna supremacja, która przejawia się np. w inicjowaniu oraz finalizowaniu rozmowy z zaproszonymi do studia gośćmi lub reporterem w przypadku RNŻ, kontroli czasu antenowego, wprowadzaniu w tematykę, podsumowaniu dyskusji, monitorowaniu porządku tematycznego, zażegnywaniu ewentualnych konfliktów miedzy interlokutorami i decydowaniu o kolejności ich wypowiedzi (Oskiera 2006: 33-45). Spójność rozmowy na poziomie semantyczno-tematycznym oraz pragmatycznym zależy od wszystkich uczestników komunikacji, jednakże podstawę nawiązywania do tego, co mówi reporter, stanowi interwencja prowadzącego-moderatora rozmowy, realizująca się np. w formie zadawanych przez niego pytań czy zamykania relacji reporterskiej. Po zdaniu przez reportera relacji z miejsca zdarzenia, prowadzący dziękuje za relację i przechodzi do przedstawiania następnej wiadomości albo dziękuje i ustosunkowuje się do tego, co mówił dziennikarz, krótko ripostując.

\subsubsection{Spójność komu nikatu multimodalnego a konstrukcja modelu sytu acji}

Standardem aktualności przekazywanych w telewizyjnych serwisach informacji nie jest już „Z ostatniej chwili”, lecz „na żywo”, w czasie rzeczywistym, z każdego niemal miejsca na Ziemi. Przekazy reporterskie w postaci RNŻ są więc stałym elementem telewizyjnych serwisów informacyjnych. Powstający przekaz operuje kilkoma modalnościami jednocześnie: dźwiękiem (słowem, efektami, muzyką) oraz obrazem (statycznym, „dynamicznym”, w formie napisów czy grafik) (Meinhof, 1994).

\subsubsection{Strategie zwiększania spójności RNŻ - analiza z perspektywy EIM}

W poprzedniej części artykułu wymienionych zostało 7 elementów składowych RNŻ. Dla konstrukcji spójnego modelu sytuacji istotne może być to, co dzieje się na granicach części komunikatu: gdy zaczyna się nowy element składowy RNŻ. Wynika to stąd, że na poziomie 
struktury (architektury w terminach TAM (Pascual i Virbel, 1996)) komunikatu elementy są od siebie oddzielone, co może zasugerować odbiorcy przejście od jednego wydarzenia do drugiego, ale także konieczność konstrukcji nowego modelu sytuacji (granica między elementami RNŻ może zostać potraktowana jako granica między dwiema niezależnymi relacjami). Jeśli pojawienie się nowego elementu składowego RNŻ związane jest $\mathrm{z}$ chęcią przekazania nowych informacji, niewiążących się bezpośrednio z poprzednimi, lub zmianą w warstwie wizualnej komunikatu multimodalnego - będzie wiązało się $\mathrm{z}$ trudnością $\mathrm{w}$ aktualizacji modelu sytuacji ze względu na niespójność pomiędzy wydarzeniami (zmianę wartości kilku indeksów naraz) (Zacks i in., 2009; 2011).

Forma powierzchniowa (surface form) komunikatu ma, zgodnie z założeniami EIM i TAM, stanowić instrukcję jego przetwarzania (konstrukcji spójnego modelu sytuacji). Z kolei celem nadawcy RNŻ jest przekazanie odbiorcy jak najwięcej informacji, a więc umożliwienia odbiorcy konstrukcjęjak najpełniejszego modelu sytuacji. Spójność komunikatu (rozumiana jako stałość wartości indeksów pomiędzy wydarzeniami) jest, zgodnie z hipotezą organizacji pamięci (Mmory Organization Hypothesis) podstawą konstrukcji spójnego modelu sytuacji, zapamiętywania treści komunikatu i przywoływania jej (Therriault i in., 2006). W związku z tym wspomniane $\mathrm{w}$ poprzednim rozdziale strategie zachowania spójności RNŻ powinny ułatwiać proces aktualizacji modelu i integracji modelu aktualnego ze zintegrowanym, o ile mają być skuteczne. Powinny wobec tego pozwalać na ustalenie wartości indeksów w taki sposób, że nowe wydarzenie różniłoby się od poprzedzającego (kończącego poprzednią część składową RNŻ) w jak najmniejszej liczbie indeksów.

\subsubsection{Zachowanie spójności - perspektywa paralelna}

Strategie zachowania spójności w perspektywie paralelnej sprowadzają się do ujednolicenia warstwy werbalnej i wizualnej komunikatu tak, by przedstawiały one tych samych bohaterów i obiekty w tym samym czasie i miejscu, uwikłanych w te same ciągi przyczynowo-skutkowe. Zwiększanie spójności RNŻ może bazować na dążeniu do całkowitej korespondencji w ramach redundancji lub kontekstu ekranowego.

W przypadku kontekstu dużą rolę w utrzymaniu spójności może odegrać komunikacja niewerbalna - m.in. gesty reportera. Gest może wspomagać przerzucanie uwagi odbiorcy na dany element kontekstu w perspektywie paralelnej (w trakcie wypowiadania frazy dotyczącej danej postaci lub obiektu) lub sekwencyjnej (po zakończeniu frazy). Może wobec tego wspomagać integrację wydarzeń.

Niezgodność wielu indeksów pomiędzy dwoma kanałami (niecałkowita korespondencja lub jej brak) może prowadzić do potraktowania przez odbiorcę informacji w poszczególnych modalnościach jako tworzących osobne wydarzenia. Nie musi to być jednak jednoznaczne z niemożnością uaktualnienia modelu sytuacji. Z modelu mogą zostać odrzucone informacje z jednego kanału, ale możliwa jest także sytuacja, w której do modelu zostaną zintegrowane dwa (lub więcej - w zależności od tego, ile modalności można wyodrębnić w komunikacie) aktualnie niezależne wydarzenia. Może to zwiększać ilość zasobów konieczną do integracji modelu, utrudnić proces aktualizacji, lub przeciwnie - wywołać bardziej aktywne przetwarzanie komunikowanych treści (McNamara i in., 1996).

Systematyzując wyniki dotychczasowych badań nad spójnością w perspektywie paralelnej (nad redundacją audio-wideo), należałoby podkreślić, że nie wszystkie wskazują, że 
Agnieszka Czoska, Agata Karaśkiewicz: Analiza mechanizmów zachowania spójności $w$ komunikacie multimodalnym na przykładzie relacji na żywo, $w$ ramach teorii modelu sytuacji; propozycja modelu spójności dla telewizyjnego przekazu reporterskiego

redundancja między kanałami audio i wideo w przekazach audiowizualnych pomaga widzom w rozumieniu przekazów i uczeniu się. Zdaniem Basil (1994a), część badań wskazuje, że im wyższa redundancja między kanałami wzrokowo-słuchowym, tym mniej wiadomości podlega utracie (wzrasta prawdopodobieństwo zapamiętania takiej informacji, bardziej przyciąga ona uwagę widzów, a to przekłada się na mniejszą ilość zasobów mentalnych (Lang, 1995) potrzebnych jest do jej przetworzenia), a w części wyniki wskazują się jej negatywny wpływ. W literaturze wspomina się także, że ten sam komunikat dla różnych osób może mieć inny wskaźnik redundancji (Popławski, Francuz 2004).

\subsubsection{Zach owanie spójności - perspektywa sekwencyjna}

Zmiana postaci i obiektu, być może $\mathrm{w}$ ogóle zmiana wartości indeksów w większości komunikatów, standardowo zachodzi sekwencyjnie - rozpoczyna się nowy element składowy RNŻ (np. setka), co wiąże się zarówno ze zmianą w kanale wideo (np. pokazanie postaci wypowiadającego się), jaki i audio (w tym przypadku może zmienić się focus, temat, jak i styl wypowiedzi). Zmiany tego typu mogą być najbardziej wymagające z punktu widzenia odbiorcy konstruującego model sytuacji tekstu. Z takiej perspektywy przetworzenie sekwencji, w której zaproszony gość stoi obok reportera (zmienia się wartość indeksu postać, nie zmienia się wartość indeksu przestrzeń) będzie łatwiejsze, niż gdy zmienią się obydwie wartości. Ponadto, im więcej zmienionych wartości indeksów, tym trudniejsza integracja wydarzenia: jeśli mówca w pierwszym przypadku zmieni temat komunikatu, zostanie to łatwiej zintegrowane (przetworzone jako wydarzenie składowe danej sytuacji), niż w przypadku zmiany przestrzeni - wówczas bardziej prawdopodobne jest uznanie takiej sekwencji za błąd nadawcy i wykluczenie jej z modelu.

Wymienione $\mathrm{w}$ poprzednim rozdziale strategie zachowania spójności RNŻ $\mathrm{w}$ momencie wprowadzania nowego elementu składowego (na granicy części komunikatu) powinny mieć na celu zmniejszenie liczby indeksów, których wartość zmienia się pomiędzy sąsiadującymi wydarzeniami. Może to polegać na przykład na:

wskazaniu explicite stałości wartości indeksów: „w tym samym miejscu”, „dosłownie przed chwilą" (opisywane wydarzenie mieści się w ramie czasowej „teraz”), zmiana planów w taki sposób, że np. kontekst ekranowy pozostaje taki sam;

podkreślaniu związków przyczynowo-skutkowych przez dodawania wskazówek leksykalnych tych relacji („dlatego”, „w związku z tym”);

zapowiadaniu zmian lub kolejnych elementów składowych RNŻ (od strony konstrukcji modelu sytuacji można przedstawić to jako dodatkowe wydarzenie, w ramach którego zmieniana jest jedynie podzbiór wartości indeksów, które musiałyby zostać uaktualnione, gdyby wprowadzić od razu wydarzenie docelowe);

zwrotach instruujących odbiorcę, na co powinien zwrócić uwagę („proszę zwrócić uwagę”, gesty wskazywania);

powtórzeniach. 
Wymienione wyżej strategie powinny ułatwiać integrację modelu sytuacji zgodnie z hipotezą wykorzystania zasobów (processing load hypothesis; integracja modelu jest tym trudniejsza, im więcej wartości indeksów uległo zmianie), hipoteza organizacji pamięci (Thierrault i in., 2006) oraz teoria ograniczonej pojemności przetwarzania informacji autorstwa Lang (1995). Część powyższych strategii ma charakter metatdyskursowy: odwołują się nie tyle do opisywanej sytuacji (będącej treścią komunikatu), co do samego komunikatu („wcześniej zapowiedzieliśmy”, „zaraz zobaczą Państwo”) (por. Wierzbicka, 1989) lub relacji nadawcaodbiorca („nasz reporter jest już na miejscu”, większość zwrotów do odbiorcy).

\section{Podsumowanie: praktyczne zastosowania modelu spójności komunikatu multimodalnego}

Odróżnienie perspektywy paralelnej i sekwencyjnej może być istotnym aspektem nie tylko porównywania spójności komunikatów multimodalnych, ale także konstrukcji bodźców na potrzeby badań nad wpływem spójności komunikatu na jego przetwarzanie, rozumienie czy pamiętanie. Badania takie mogłyby wskazać, czy zaburzenia w spójności jednego rodzaju mają silniejszy w pływ na przetwarzanie komunikatu niż drugiego oraz jak spójność mierzona w kategoriach identyczności indeksów przekłada się na postrzeganie komunikatu jako spójnego, interesującego, przekonującego przez odbiorcę. Przedstawione rozważania teoretyczne oraz cytowane prace empiryczne pozwalają na postawienie kilku ważnych pytań. Po pierwsze, istotne wydaje się ustalenie, czy zwiększenie spójności komunikatu (przejście ze spójności niecałkowitej do całkowitej) zwiększa jego zrozumiałość lub poziom zapamiętania. Jeśli wziąć pod uwagę wyniki badań McNamary i in. nad czytaniem (McNamara i in., 1996; McNamara i Kintsch, 1996; McNamara 2001), zwiększanie spójności może wpływać pozytywnie na pamiętanie formy powierzchniowej komunikatu (dosłowne zapamiętanie), ale nie na rozumienie ( uczenie się nowych informacji i stosowanie ich do rozwiązywania problemów, umiejętność streszczania i parafrazowania tekstu). Być może tendencja taka utrzymuje się dla innych rodzajów komunikatu. Poza tym, można powiązać badania w paradygmacie EIM z badaniami nad pamięcią roboczą i stawiać pytania o to, jakie koszty wiążą się z utrudnieniami w integracji modelu (częstymi zmianami wartości indeksów) oraz koniecznością integrowania kilku wydarzeń jednocześnie (np. osobnych wydarzeń podawanych w różnych modalnościach). 
Agnieszka Czoska, Agata Karaśkiewicz: Analiza mechanizmów zachowania spójności $w$ komunikacie multimodalnym na przykładzie relacji na żywo, $w$ ramach teorï modelu sytuacji; propozycja modelu spójności dla telewizyjnego przekazu reporterskiego

\section{Bibliografia}

Ädel, A. (2006). Metadiscourse in l1 and l2 english. John Benjamins Publishing Company. Allan S. (2006). Kultura newsów, Wydawnictwo Uniwersytetu Jagiellońskiego, Kraków.

Antas A. (1981). Projekt metodologii badań relacji obraz-słowo w przekazie telewizyjnym, Zeszyty Prasoznawcze 2.

Bellert I. (1971). O pewnym warunku spójności tekstu. W: M. R. Mayeonwa (red.) O spójności tekstu. Wrocław-Warszawa: Zakład Narodowy Imienia Ossolińskich, Wydawnictwo PAN.

Basil M. D. (1994a). Multiple resource theory, I: Application to television viewing. Communication Rresearch, 21, 2 177-208.

Beaugrande de R-A, Dressler W. U. (1990). Wstęp do lingwistyki tekstu. Warszawa, Państwowe Wydawnictwo Naukowe.

Bednarek M., Caple H. (2012). News discourse. Chennai, Continuum.

Brosius H. B. (1989). Influence of presentation features and news content on learning from television news. Journal of Broadcasting \& Electronic Media, 33, 1-14.

Brunyé, T. T. i Taylor, H. A. (2007). Working memory in developing and applying mental models from spatial descriptions. Journal of memory and language. 58(3),. 701-729.

Dobrzyńska T. red. (1993). Tekst. Próba syntezy. Warszawa, Instytut Badań Literackich.

Drew D. G., Grimes T. (1987). Audio-visual redundancy and TV news recall. Communication Research, 14, 452-461.

Duszak A. (1998). Teskt, dyskurs, komunikacja międzykulturowa. Warszawa, Wydawnictwo PWN.

Ericsson, K. A. i Kintsch, W. (1995). Long-term working memory. Psychological review. 102(2), pp. 211-245.

Francuz P. (2002). Rozumienie przekazu telewizyjnego. Lublin, Towarzystwo Naukowe KUL. Hagoort, P. i van Berkum, J. (2007). Beyond the sentence given. Philosophical transactions of the royal society. 362, pp. 801-811.

Hald, L. A., Steenbeek-Planting, E. G. i Hagoort, P. (2007). The interaction of discourse context and world knowledge in online sentence comprehension. evidence from the $\mathrm{n} 4 \mathrm{Oo}$. Brain Research(1146), 210-218.

Hyland, K. (2005). Metadiscourse: exploring interaction in writing. Continuum.

Jacobson, R. (1989). Poetyka w świetle językoznawstwa. W: W poszukiwaniu istoty języka. Wybór pism. Tom 2.

Kurby, Ch. A. I Zacks, J. M. (2012). Starting from scratch and building brick by brick in comprehension. Memory \& Cognition 4O(5), pp. 812-826. 
Kutas, M. i Federmeier, K. D. (2010). Thirty years and counting: Finding meaning in the n40o component of the event-related brain potential (ERP). The Annual Review of Psychology, 62 , 621-647.

Lang, A. (1995). Defining audio/video redundancy from a limited capacity information processing perspective. Communication Research, 22, s. 86-115.

Leathers D. (2007). Komunikacja Niewerbalna, Warszawa, PWN.

Lemarié, J., Robert F. Lorch, J., Eyrolle, H. i Virbel, J. (2008). Sara: A text-based and readerbased theory of signaling. Educational Psychologist,43 (1), 27-48.

Lindernholm, T., Virtue, S., Tzeng, Y i van den Broek, P. (2004). Pluctuations in the availability of information during reading: capturing cognitive processes using the landscape model. Discourse processes 37(2), pp. 165-186.

Lorch Jr, R., Lemarié, J. i Grant, R. (2011). Three information functions of headings: A test of the sara theory of signaling. Discourse Processes, 48 (3), 139-160.

Magdoń A. (2005). Reporter i jego warsztat. Kraków, Universitas.

Magliano, J. P., Miller, J. I Zwaan, R. A. (2001). Indexing space and time in film understanding. Applied Cognitive Psychology, 15, pp. 533-545.

McNamara, D. S. (2001). Reading both high-coherence and low-coherence texts: Effects of text sequence and prior knowledge. Canadian Journal of Experimental Psychology, 55 (1), 51-62.

McNamara, D. S. I Kintsch, W. (1996). Learning from texts: Effects of knowledge and text coherence. Discourse processes, 22, pp. 247-288.

McNamara, D. S., Kintsch, E., Butler Songer, N. i Kintsch, W. (1996). Are good texts always better? Interactions of text coherence, background knowledge, and levels of understanding in learning from text. Cognition and Instruction, 14 (1), 1-43.

McNamara, D.S. i Magliano, J. (2009). Toward a Comprehensive Model of Comprehension w: Brian Ross (red.) The Psychology of Learning and Motivation, Vol. 51, Burlington: Academic Press, pp.297-384.

Martinec R., Salway A., (2005). A system for image-text relations in new (and old) media, Visual Communication, 4 (3), 337-71.

Mayenowa M. R. (red) (1971). O spójności tekstu. Wrocław - Warszawa: Zakład Narodowy im. Ossolińskich, Wydawnictwo PAN.

Meinhof, U.H. (1994). Double talk in news broadcasts: a cross-cultural comparison of pictures and texts in television news. w: D. Graddol and O. Boyd-Barrett (eds), Media Texts: Authors and Readers. Clevedon: Open Univeristy Press, pp. 212-23.

Montgomery, M. (2007). The discourse of Broadcast News: A Linguistic Approach. Abingdon/New York: Routledge.

Niczyperowicz A., (red.) (2001) Dziennikarstwo od kuchni. Poznań, TS Wydawnictwo, Oskiera A. (2006). Strategie konwersacyjne $w$ dialogu radiowym. Leksem, Łask. 
Agnieszka Czoska, Agata Karaśkiewicz: Analiza mechanizmów zachowania spójności $w$ komunikacie multimodalnym na przykładzie relacji na żywo, $w$ ramach teorï modelu sytuacji; propozycja modelu spójności dla telewizyjnego przekazu reporterskiego

Ożdżyński J., (1978). Relacja radiowa i komentarz telewizyjny w ujęciu składniowoinformacyjnym. w: T. Skubalanka (red.), Studia nad składnią polszczyzny mówionej, Wrocław.

Pascual, E. i Virbel, J. (1996). Semantic and Layout Properties of Text Punctuation. w: Proceedings of the Association for Computational Linguistics Workshop on Punctuation, pp. 41-48.

Pavio A. (1969). Mental imagery in associative learning and memory. Psychological

Reuiew, 76, 241-263.

Persson, P. (1998). Coherence and Inference Generation in Cinematic Texts. prezentacja na The Society for Text and Discourse annual conference, Madison, Wisconsin.

Płażewski J., (1982). Język filmu, Wydawnictwo Artystyczne i Filmowe, Warszawa.

Radvansky, G. A. i Copeland, D. E. (2004). Working memory span and situation model processing. American Journal of Psychology 117(2), pp. 191-213.

Ray, V. (2003). The television Handbook: An Insider`s Guide to being a Great Broadcast Journalist. London: Macmillan.

Rapp, D. N i Kendeou, P. (2007). Revising what readers know: Updating text representations during narrative comprehension. Memory \& Cognition 35(8), pp. 2019-2032.

Rapp, D. N. I Taylor, H. A. (2004). Interactive Dimensions in the Construction of Mental Representations for Text. Journal of experimental psychology 30(5), pp. 988-1001.

Rinck, M. i Weber, U. (2003). Who when where: An experimental test of the event-indexing model. Memory \& Cognition, 31 (8), 1284-1292.

Saloni Z. (1971). Definicja spójności tekstu. w: R. Mayenowa (red.), O spójności tekstu, Wrocław-Warszawa, Zakład Narodowy im. Ossolińskich, Wydawnictwo PAN.

Therriault, D. J., Rinck, M. i Zwaan, R. A. (2006). Assessing the influence of dimensional focus during situation model construction. Memory \& Cognition 34(1), pp. 78-89.

Tzeng, Y., van den Broek, P., Kendeou, P. i Lee, Ch. (2005). The computational implementation of the landscape model: modeling inferential processes and memory representations of text comprehension. Behavior research methods 37(2), PP. 277-286.

Uszyński J., (2004). Telewizyjny pejzaż genologiczny, Warszawa, Biblioteka Zeszytów Telewizyjnych.

van Berkum, J., Brown, C., Zwitserlood, P., Kooijman, V. i Hagoort, P. (2005). Anticipating upcoming words in discourse: Evidence from ERPs and reading times. Journal of Experimental Psychology: Learning, Memory, and Cognition, 31 (3), 443.

van Berkum, J, Brown, C. i Hagoort, P. (1999). Early Referential Context Effects in Sentence Processing: Evidence from Event-Related Brain Potentials. Journal of memory and language 41, pp. 147-182. 
Walma van der Molen, J. , i van der Voort, T. (2000). The impact of television, print and audio on children 's recall of the news. A study of three alternative explanations for the dualcoding hypothesis. Human Communications Research, 26, 3-26.

Wesołowska D., (1980). Monolog telewizyjny. Próba typologii. Zeszyty Prasoznawcze, 4.

Van Leeuwen, T. (1991). Conjunctive structure in documentary film and television, Continuum, 5 (1), 76-114.

Zacks, J. M., Speer, N. K. i Reynolds, J. R. (2009). Segmentation in Reading and Film Comprehension. Journal of experimental psychology. 138(2), pp. 307-327.

Załazińska A. (2006). Niewerbalna struktura dialogu. W poszukiwaniu polskich wzorów narracyjnych i interakcyjnych zachowań komunikacyjnych, Kraków, Universitas.

Zwaan, R. A. (1999). Situation Models: The Mental Leap Into Imagined Worlds. Current directions in psychological science. 8(1), pp. 15-18.

Zwaan, R. A., Langston, M. C. i Graesser, A. C. (1995). The construction of situation models in narrative comprehension: An event-indexing model. Psychological science 6(3), pp. 292297.

Zwaan, R. A. i Madden, C. J. (2004). Updating situation models. Journal of Experimental Psychology: Learning, Memory, and Cognition 30(1), 283-288.

Zwaan, R. A. i Radvansky, G.. A. (1998). Situation models in language comprehension and memory. Psychological bulletin, 123 (2), 162-185.

Zon L., (1998) O montażu w filmie, Warszawa, Centrum Animacji Kultury,.

Żórawski K., (2004) Dtugi stót. Warszawa, Biblioteka Zeszytów Telewizyjnych.

Żydek-Bednarczuk (2005), Wprowadzenie do lingwistycznej analizy tekstu, Kraków, Universitas. 